\title{
直動玉軸受の寿命に関する研究（第 $\mathbf{1}$ 報）*
}

\author{
一一転 動 体 荷 重一
}

清 水茂夫** 井沢実**

Study on the Fatigue Life of Linear Motion Ball Bearing (1st Report)

-On the Roll Body Loads in Relation to the Basic Load Rating of the Bearing-

Shigeo Shimizu, Minoru Izawa

As the first report, this paper deals with a calculation method of the numbers of stress cycles at the raceway surfaces of the outer sleeve and the shaft, and the equation of the roll body loads. Some points are discussed concerning the calculated results for various shaft strokes. The principal results are as follows:

(1) Applying to the new calculation method, which splits both raceway surfaces into small portions, the numbers of stress cycles of those raceways are counted accurately.

(2) The roll body loads are considerably small in the case of short shaft stroke, but when the ratio between the shaft stroke and the raceway length of outer sleeve $\left(l_{s} / l\right)$ becomes greater than 1 , the roll body load of outer sleeve $\left(Q_{c o}\right)$ has a constant value while the one of shaft $\left(Q_{c s}\right)$ has comparatively high increasing ratio.

(3) In the case of linear motion ball bearing, probability of flaking due to rolling contact fatigue on the shaft becomes higher than that of the outer sleeve, because of $Q_{c o} / Q_{c s}=$ 1. 25-1. 17. Meanwhile, in the case of ball spline, $Q_{c o} / Q_{c s} \simeq 1$ for $l_{s} / l \leqq 1$ and $Q_{c o} / Q_{c s}=0.92$ for $l_{s} / l=10$, then the probability of flaking on the outer sleeve becomes higher than that of the shaft. And, if the conformity between ball and raceway groove is reduced, the roll body loads decrease extremely. Further, in the case of ball guide way, the roll body loads are nearly equal to those of the linear motion ball bearing.

\section{1. ま え がき}

直動玉軸受は，一般の回転用玉軸受と同様に外部荷重 $F(\mathrm{kgf})$ に対して

$$
\left.L=\left(\frac{C}{F}\right)^{3} \quad \text { (単位は } 50 \mathrm{~km} \simeq 2000 \mathrm{kin}\right)
$$

で与えられる寿命 $L$ を基準にして走行表命の計算がな されている．ここで， $C$ : 基本動定格荷重 (kgf).

$C$ の一般式は Lundberg らの寿命理論1) に準拠してす でに高田2)によって導かれているが，高田は転動体荷重 式を導く際に応力繰返し数および応力を受计る長さ，す なわち応力体積の処理にかなり巨視的な考え方を用いて いるら光, 軸に対する係数 $\omega$ と $\Omega$ との近似にも疑点があ り,さらに $C$ を求める際に軸受内の負荷分布状態を考慮 していない.

転動体荷重式と軸受内負荷分布式は寿命理論において 最も重要な数值を与えるものであり，これらが整理され

\footnotetext{
* 原稿受付 昭和 53 年 12 月 21 日. 昭和 52 年度精機学会秋 季大会学術講演会（昭和 52 年 11 月 15 日）にて発表。
}

** 正 会 員 明治大学工学部 (川崎市多摩区生田 5158)
てはじめて基本動定格荷重も明らかにでき，軸受寿命も 推定することができるわけである．筆者らは，従来直動 玉軸受の負荷分布に関して理論と実験の両面から系統的 に究明してきた 3 ）。をた，寿命試験も昭和 51 年以来実施 継続中である.

そこで本報では, 直動玉軸受の寿命に関する研究の第 1 報として, まずLundberg らの寿命理論をもとにして, 軸受内各玉列の玉の転動状態を解明し，応力体積ならび に応力繰返し数が外筒と軸のそれぞれの軌道面において 様々に異なる状態での転動体荷重式を導き，これを用い て種々の軸ストロークにおける軸受外筒ならびに軸に関 する転動体荷重值を計算した結果を報告する。また，直 動玉軸受の場合と同様な手法でボールスプラインや転が り案内の場合の転動体荷重式も得ることができるので, これらの場合についても算出結果を報告する.

\section{2. 転動体荷重の理論式}

\section{1 転動体荷重の基礎式と寿命式中の係数}

直動玉軸受の転動疲れ寿命が，一般の転がり軸受と同 様に接触表面下 $z_{0}$ の深さに打忷る動的最大せん断応力 
振幅 $\tau_{0}$ によって支配されるものとすれば,材料の累積残 存確率 $S$ と総応力繰返し数 $N$ ならびに玉接触部の 応力 体積 $V$ などとの間に Lundberg らが Weibull の統計理 論を応用して導いた式

$$
\ln \frac{1}{S} \propto \tau_{0}{ }^{c} N^{e} z_{0}{ }^{-h} V
$$

が成立する，ただし，直動玉軸受の場合には $50 \mathrm{~km}$ を定 格寿命すなわち単位走行距離にとっているから，片道 $l_{s}$ $(\mathrm{mm})$ の直線運動ストロークに対する軌道面上のある点 が受ける応力繰返し数を $u$ と扔くと, その点の総応力繰 返し数 $N$ は

$$
N=\frac{50 u}{l_{s}} L \quad \text { (単位は } 10^{6} \text { 回） }
$$

のように考えることができる.

また, 応力体積 $V$ は軌道面における接触だ円の形状が

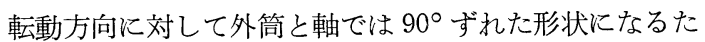
め (図 1 参照),

$$
\left.\begin{array}{l}
V_{o} \propto\left(a z_{0} D_{n}\right)_{o} \\
V_{s} \propto\left(b z_{0} D_{n}\right)_{s}
\end{array}\right\}
$$

で与えられる．ここで，添字 $o, s$ はそれぞれ外筒と軸の 接触を表し, $a, b$ はそれぞれ接触だ円の長短軸半径, $D_{n}$ は応力を受ける長さを表す。

式 (2), (4) 飞おおる Hertz 諸量は次式で表せる.

$$
\left.\begin{array}{l}
a=\mu \sqrt[3]{\frac{3 Q}{E_{0} \sum \rho}}, \quad b=\nu \sqrt[3]{\frac{3 Q}{E_{0} \sum \rho}} \\
\tau_{0}=T \cdot q, \quad z_{0}=\zeta \cdot b
\end{array}\right\}
$$

ここで, $\mu, \nu: a, b$ 飞対する助変数, $Q$ : 転動体荷重, $\sum \rho:$ 接触物体間の曲率和, $T, \zeta: \tau_{0}, z_{0}$ 飞対する助変数, $E_{0}: m^{2} E /\left(m^{2}-1\right), m, E:$ ポアソン数, 縦弾性係数, $q: 3 Q / 2 \pi a b$ (最大 Hertz 応力).

式 (3) (5) を比例式 (2)へ代入し整理すると次式を得 る.

$$
\begin{aligned}
& \frac{Q}{D_{a}} L^{\frac{3 e}{c-h+2}}=A_{1} \phi_{i} D_{a}^{-\frac{3(3-h)}{c-h+2}}\left[\frac{50}{l_{s}}\right]^{-\frac{3 e}{c-h+2}} \\
& i=o \text { あるいは } s \\
& \text { ここで, } \\
& A_{1} \propto\left[\ln \frac{1}{S} \frac{\zeta_{1}^{h-1}}{T_{1}^{c}}\right]^{\frac{3}{c-h+2}}\left[\begin{array}{c}
3 \\
E_{0}^{-}
\end{array}\right]^{2 c+h-2} \\
& \phi_{o}=\left[\left(\frac{T}{T_{1}}\right)^{c}\left(\frac{\zeta_{1}}{\zeta}\right)^{h-1} \frac{\left(D_{a} \sum \rho\right)^{\frac{2 c+h-2}{3}}}{\mu^{c-1} \nu^{c+h-1}} \frac{D_{n o}}{D_{a}} u_{o}^{e}\right]^{-\frac{3}{c-h+2}} \\
& \phi_{s}=\left[\left(\frac{T}{T_{1}}\right)^{c}\left(\frac{\zeta_{1}}{\zeta}\right)^{h-1} \frac{\left(D_{a} \sum \rho\right)^{2 c+h-2}}{\mu^{c} \nu^{c+h-2}} \frac{D_{n s}}{D_{a}} u_{s}^{e}\right]^{-\frac{3}{c-h+2}}
\end{aligned}
$$

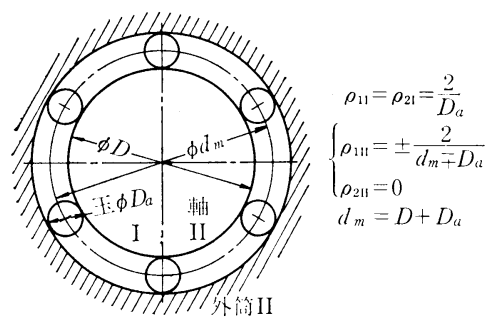

曲漳のとりノ

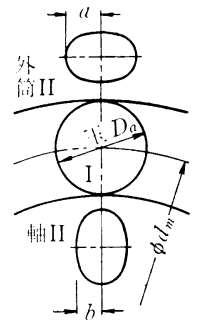

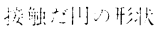

図 1 主平面 1 における曲率と接触だ円

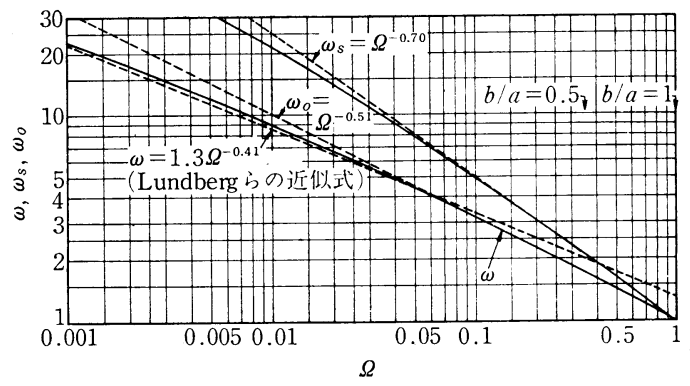

図 $2 \omega$ と $\Omega$ の関係

それぞれ $c=31 / 3, h=7 / 3, \quad e=10 / 9, A_{1}=112.2(\mathrm{kgf}$. $\mathrm{mm}$ 単位系) であるから, 式 (6) 飞これらの諸值を用い, $L=1$ すなわち $50 \mathrm{~km}$ 走行時の転動体荷重を $Q_{\mathrm{c}}$ で表す と

$$
Q_{c}=30.406 \phi_{i} D_{a}^{1.8} l_{s}^{1 / 3}
$$

となる。式 (10)が転動体荷重の基礎式であるが，次に係 数 $\phi_{i}$ を求めてみる. まず,式 (8), (9) 中の $D_{a} \sum \rho$ は図 1 に 打いて

$$
F_{(b / a)}=\frac{\left|\rho_{1 \mathrm{I}}-\rho_{2 \mathrm{I}}+\rho_{1 \mathrm{II}}-\rho_{2 \mathrm{II}}\right|}{\sum \rho}, \sum \rho=\frac{4}{D_{a}} \pm \frac{2}{d_{m} \bar{\mp} D_{a}}
$$

とおくことにより

$$
D_{a} \sum \rho=\frac{4}{1+F_{(b / a)}}\left\{1+\frac{D_{a} / d_{m}}{2\left(1 \mp D_{a} / d_{m}\right)}(1 \pm 1)\right\}
$$

のように関係づけることができる，ここで，符号は上側 が軸，下側が外筒を表す。

式(11)を式 (8), (9)へ代入し， $D_{n}$ とu以外の項を一括し $\tau$

$$
\begin{aligned}
& \omega_{o}=\left\{1+F_{(b / a)}\right\}^{2.1}\left(\frac{T_{1}}{T}\right)^{3.1}\left(\frac{\zeta}{\zeta_{1}}\right)^{0.4} \mu^{2.8}{ }^{2.53} \\
& \omega_{s}=\left\{1+F_{(b / a)}\right\}^{2.1}\left(\frac{T_{1}}{T}\right)^{3.1}\left(\frac{\zeta}{\zeta_{1}}\right)^{0.4} \mu^{3.1} \nu^{3.2} \\
& \Omega_{i}=\frac{1-F_{(b / a)}}{1+F_{(b / a)}}
\end{aligned}
$$

とおき， $\omega$ と $\Omega$ との関係を $(b / a)$ を助変数にして求める 之図 2 が得られ，次の近似式が成立する. 


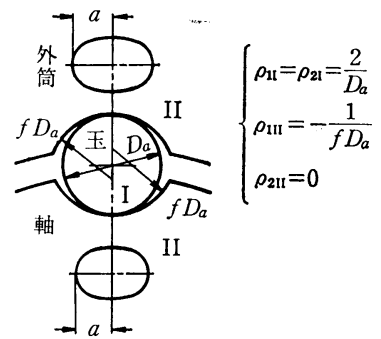

図 3 ボールスプラインみぞの場合

$$
\begin{aligned}
& \omega_{0} \simeq \Omega_{o}{ }^{-0.51}=\left(1+\frac{D_{a}}{d_{m}}\right)^{0.51} \\
& \omega_{s} \simeq \Omega_{s}{ }^{-0.70}=\left(1-\frac{D_{a}}{d_{m}}\right)^{-0.70}
\end{aligned}
$$

したがって，式(11)〜(16)から

$$
\begin{aligned}
& \phi_{o}=0.0767\left(1+\frac{D_{a}}{d_{m}}\right)^{0.51}\left(\frac{D_{a}}{D_{n o}}\right)^{0.3} u_{o}^{-\frac{1}{3}} \\
& \phi_{s}=0.0767\left(1-\frac{D_{a}}{d_{m}}\right)^{1.4}\left(\frac{D_{a}}{D_{n s}}\right)^{0.3} u_{s}^{-\frac{1}{3}}
\end{aligned}
$$

を求められる. ここで, 式 (17), (18) の右辺初項定数值は, 一般の玉軸受と直動玉軸受との応力を受ける長さの取り 方の違いによる補正值すなわち $\pi^{0.3}$ 倍を含めて定めてい る.

また，最近広く使用されるようになってきた図 3 に示 すボールスプラインの場合には Lundberg らの近似式を そのまま適用することができるから

$$
\begin{gathered}
\omega \simeq 1.3 \Omega^{-0.41}, \quad \Omega=\frac{2 f-1}{2 f}(f=0.5175 \sim 0.54) \text { より } \\
\phi_{i}=0.0997\left(\frac{2 f-1}{2 f}\right)^{-0.41}\left(\frac{D_{a}}{D_{n i}}\right)^{0.3} u_{i}{ }^{-\frac{1}{3}}
\end{gathered}
$$

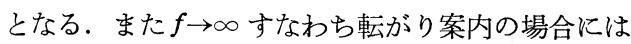

$$
\begin{aligned}
\omega=\Omega & =1, \quad F_{(b / a)}=0 \text { より } \\
\phi_{i} & =0.0767\left(\frac{D_{a}}{D_{n i}}\right)^{0.3} u_{i}^{-\frac{1}{3}}
\end{aligned}
$$

$$
\text { となる. }
$$

\section{2 応力繰返し数と応力を受ける長さ}

直動玉軸受における外筒と軸の両軌道面が受ける応力 繰返し数は, 軸ストローク $l_{s}$ によって複雑に変化するた め, 一般の転がり軸受に比べるとかなり複雑なものとな る. 筆者らは任意の軸ストロークに対する応力繰返し数 を求める方法を考案した.

すなわち, 図4 に示すように外筒, 玉, 軸に対する直 線座標の原点を軸受左端にとり，外筒と軸はそれぞれ $L$ および $N$ 等分の微小間隔（例えば $D_{a} / 20$ ) に刻まれてい るものとする.

まず, 外筒軌道面上のある点 $X(i)$ に着目すると, 点

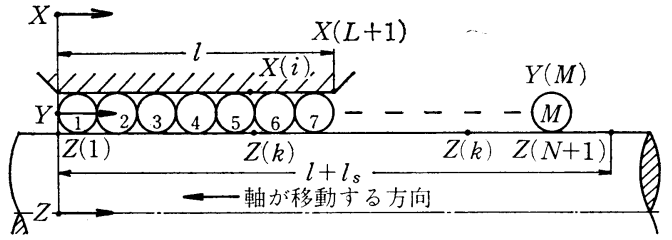

図 4 外筒, 玉, 軸に対する直線座標

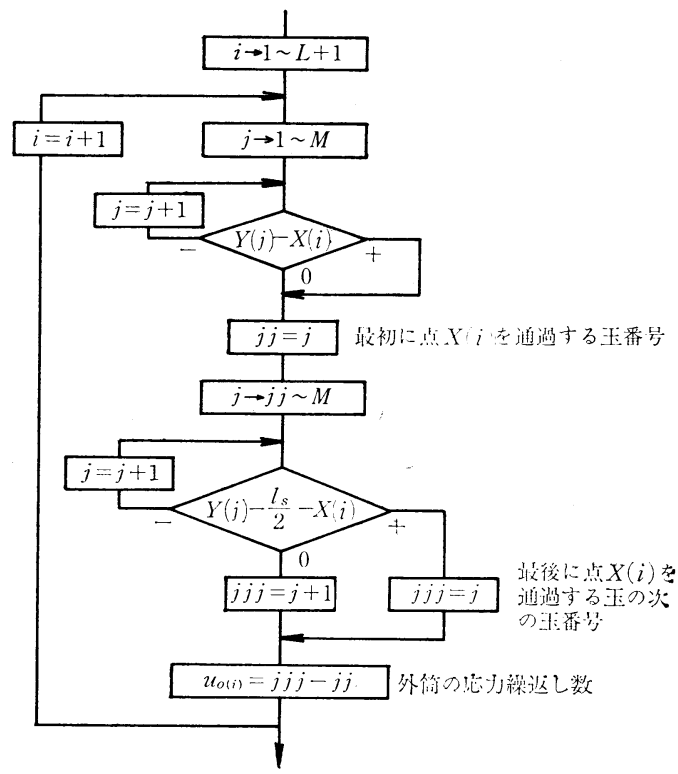

図 5 軸受外筒の応力繰返し数を求める流れ図

$X(i)$ の応力繰返し数はその点を玉が何個通過するかに よって求めることができる.この場合流れ図，図 $\mathbf{5}$ にお

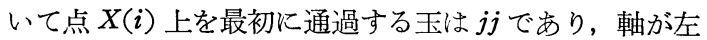
方へ $l_{s}$ 移動すれば玉は $l_{s} / 2$ だけ移動し，最後に点 $X(i)$ を通過する玉の次の玉が $j j j$ となる.ゆえに, 外筒の応 力繰返し数 $u_{o(i)}$ は次式で求められる.

$$
u_{o(i)}=j j j-j j \quad(i=1,2, \cdots L+1)
$$

また, 軸の場合は軸上のある点 $Z(k)$ が軸受内で玉を 何個追い越すかによって定めうる. したがって, 流れ図, 図 6 に打いて点 $Z(k)$ が始めから軸受内にある場合と軸 受外にある場合とに分けて考え，まず点 $Z(k)$ が軸受内 で最初に追い越す王 $j j$ みつけ，次に軸の移動ととも に点 $Z(k)$ が軸受内を通過するかあるいは軸受内のある 位置で停止するかによって最後に追い越した玉 $j j j$ み つける.これより, 軸の応力繰返し数 $u_{s(k)}$ は次式で求め られる。

$$
u_{s(k)}=j j j-j j+1 \quad(k=1,2, \cdots, N+1)
$$

次に, 応力を受ける長さ $D_{n}$ は同一応力繰返し数の軌

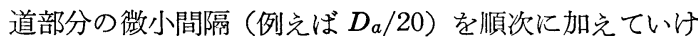




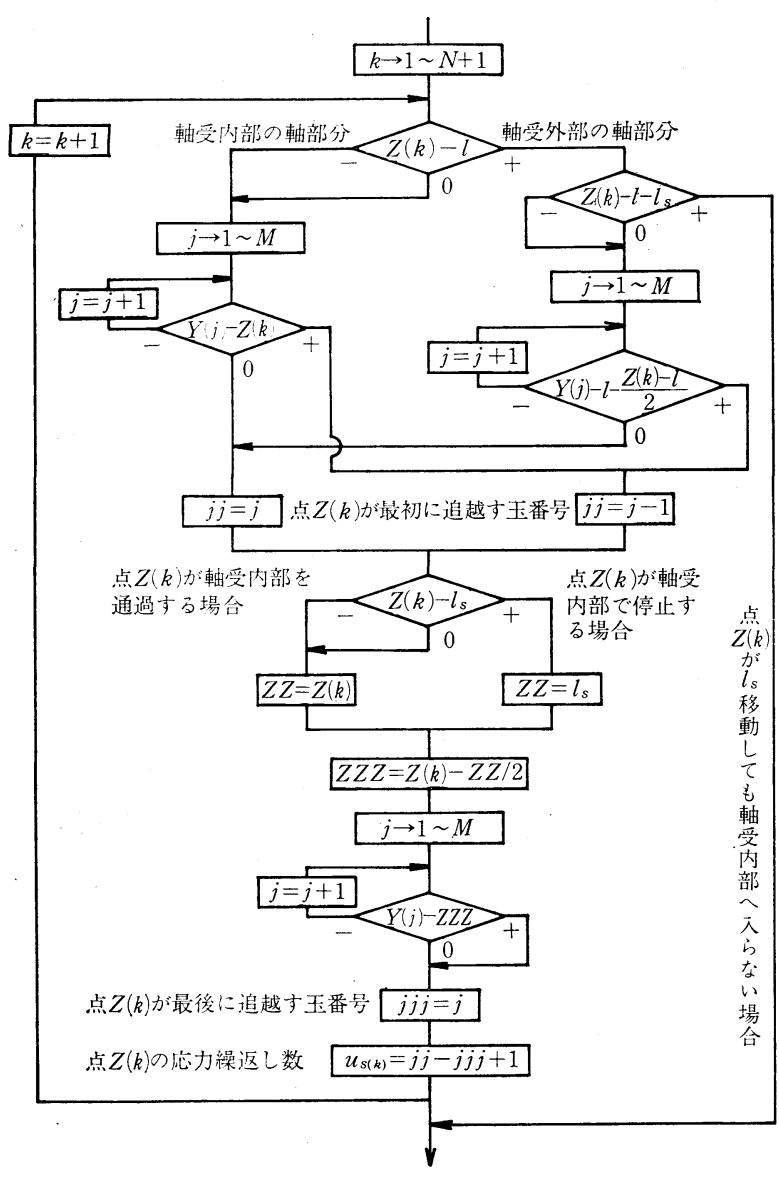

図 6 軸の応力繰返し数を求める流れ図

ばよいから, 次式のように求められる.

$D_{n o}\left(u_{0}\right)=\frac{D_{a}}{20} \times($ 外筒で発生した同一 繰返し数 $u_{o(i)}$ の総和)

$D_{n s}\left(u_{s}\right)=\frac{D_{a}}{20} \times($ 軸で発生した同一繰 返し数 $u_{s(k)}$ の総和)

ただし，微小な軸ストロークの場合すなわち $l_{s}<2 \kappa D_{a}$ $\left(\kappa D_{a}\right.$ ：球間ピッチ)の場合には

$$
\left.\begin{array}{l}
u_{o}=u_{s}=1 \\
D_{n o}=D_{n s} \simeq \frac{l_{s} Z}{2} \text { (Z: } 1 \text { 列中の玉数) }
\end{array}\right\}
$$

ま, 式 (2) において確率係数を $\boldsymbol{k}_{(u)}$ とすれば, 軌道 面の各部分が独立に同一寿命 $L$ をつ確率 $S_{(u)}$ は

$$
\ln \frac{1}{S_{(u)}}=k_{(u)} Q^{w} L^{e}
$$

ここに, $w=(c-h+2) / 3=p e=10 / 3$ と置くこ

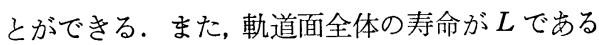
確率 $S$ は

$$
\ln \frac{1}{S}=\sum_{u=\min }^{\max } \ln \frac{1}{S(u)}=Q^{w} L^{e} \sum_{u=\min }^{\max } k_{(u)} \quad \text { (26) }
$$

となり, 定格寿命すなわち $L=1$ の場合には $S_{(u)}=$ $0.9, Q \rightarrow Q_{c}(u) ; S=0.9, Q \rightarrow Q_{c}$ とすることがで きるから

$$
\boldsymbol{Q}_{c}=\left\{\sum_{u=\min }^{\max } \boldsymbol{Q}_{c}(u)^{-w}\right\}^{-\frac{1}{w}}
$$

を求めることができる。

以上の結果より，外筒と軸に対する 1 列全体と しての転動体荷重 $Q_{c i}$ は

$$
\begin{aligned}
Q_{c i} & =\left[\sum_{u i=\min }^{\max } Q_{c i}\left(u_{i}\right)^{-w}\right]^{-\frac{1}{w}} \\
& =f_{c i} D_{a}^{2.1} l_{s}^{1 / 3}\left[\sum_{u i=\min }^{\max }\left\{D_{n i}\left(u_{i}\right)^{0.3} u_{i}^{1 / 3}\right\}^{w}\right]^{-\frac{1}{w}}
\end{aligned}
$$

のように表すことができる.

また， $l_{s}<2 \kappa D_{a}$ の場合には次式を用いてもよ W.

$$
Q_{c i}=f_{c^{\prime} i} D_{a}^{2.1} Z^{-0.3} l_{s}^{1 / 30}
$$

式 (28), (29) 中の係数はそれぞれ表 1 に示す.

\section{3. 計算結果と考察}

以下の計算では表 2 に示す呼び 径 $30 \mathrm{~mm}$ の直動玉軸 受の諸元を用いることにする，また，軸受内の球間ピッ チには実測值4)を用いることとする.この場合， $\kappa^{\prime} D_{a}$ は 軌道面上の玉のポテンシャルが保持器ポケット内の玉よ り大きい列で軌道面上 1 か所に必ず発生する球間ピッチ であって，玉組込み時に生じる球間すきまに対応する量 が現れたものとなる。

まず，軸ストローク $73.7 \mathrm{~mm}$ の場合に対する各軌道 面に拈ける1ストローク当たりの応力繰返し数を求めた
のようにしてもよい.

\section{3 応力繰返し数が軌道面上の 各部} で異なる場合の転動体荷重と 1 列全体としての転動体荷重

直動玉軸受の応力繰返し数は, 軌道面 のそれぞれの部分で異なるから, 寿命も また各部分に対応して異なってくる。い
表 1 係数 $f_{c i}$ と $f_{c^{\prime} i}$ の式

\begin{tabular}{l|l|l}
\hline 軸受形式 & \multicolumn{1}{|c|}{$f_{c i}\left(l_{s} \geqq 2 \kappa D_{a}\right.$ の場合 $)$} & \multicolumn{1}{|c}{$f_{c^{\prime} i}\left(l_{s}<2 \kappa D_{a}\right.$ の場合 $)$} \\
\hline 直動玉軸受 & $f_{c o}=2.3322\left(1+D_{a} / d_{m}\right)^{0.51}$ & $f_{\mathrm{c}^{\prime} \cdot}=2.87\left(1+D_{a} / d_{m}\right)^{0.51}$ \\
& $f_{c s}=2.3322\left(1-D a / d_{m}\right)^{1.40}$ & $f_{c^{\prime} s}=2.87\left(1-D_{a} / d_{m}\right)^{1.40}$ \\
ボールスプライン & $f_{c o}=f_{c s}=3.032\left(\frac{2 f}{2 f-1}\right)^{0.41}$ & $f_{c^{\prime} o}=f_{c^{\prime} s}=3.73\left(\frac{2 f}{2 f-1}\right)^{0.41}$ \\
転がり案内 $(f \rightarrow \infty)$ & $f_{c o}=f_{c s}=2.3322$ & $f_{c^{\prime} o}=f_{c^{\prime} s}=2.87$ \\
\hline
\end{tabular}


表 2 軸 受 諸 元

\begin{tabular}{l|l}
\hline 軸 径 & $D=30 \mathrm{~mm}$ \\
球 径 & $D_{a}=3.969 \mathrm{~mm}$ \\
玉列数 & 6 \\
軌道面長さ & $l=32.5 \mathrm{~mm}$ \\
球間ピッチ & $\kappa D_{a}=4.215 \mathrm{~mm}$ \\
& $\kappa^{\prime} D_{a}=6.465 \mathrm{~mm}$ \\
\hline
\end{tabular}

一例は図 7 に示す．同図は軌道面内へ入ってくる玉を順 次軸上に展開した状態で表している．これより，外筒の 場合には玉並び状態が一定であれば，応力繰返し数は 9 , $8,9,8, \cdots$ 回を交互に繰返すが，軌道上に $\kappa^{\prime} D_{a}$ が現れる 列では, その影響を受けて 7 回の場合も生じることがわ かる. 一方，軸の場合には，軸ストロークがいくら長く なっても最大応力繰返し数は外筒軌道面上の玉数 $Z$ の 偶数, 奇数に応じて

偶数の場合: $u_{s \max }=Z / 2$

奇数の場合: $u_{s \min }=Z / 2+0.5$
を越えて働くことはあり得ない. また, 最小応力繰返し 数は 1 であるが, 図から明らかなように, 直動案内作用 に参加する軸範囲であっても圧縮力を一度も受けない軸 部分が現れてくることがわかる.

次に, 図 7 の結果に対して応力繰返し数 $u_{i}(i=0, s)$ と 応力を受ける長さ $D_{n i}\left(u_{i}\right)$ ならびにそれらに対応する各 部の転動体荷重 $Q_{c i}\left(u_{i}\right)$ の関係を求めた例を図 8 に示 す.これより， $u_{i}$ と $D_{n i}\left(u_{i}\right)$ が小さいほどそれらに対応 する各部の転動体荷重は大きくなることがわかる.

また, 式(28)を用い, 軸ストロークに対する外筒と軸の 1 列全体としての転動体荷重 $Q_{c i}$ を計算すると図 9 が得 られる.これより, 総合した $Q_{c i}$ は図 8 で示した $Q_{c i}\left(u_{i}\right)$ のらちで最も小さい值よりさらに小さくなること泫かか る.そして, 微小ストローク時の $Q_{c i}$ はかなり低く, $l_{s} / l$ すなわち軸ストロークと外筒軌道面長さとの比が 1 を越 えると $Q_{c s}$ の増大率はかなり高くなり，一方， $Q_{c o}$ は一 定值をとる傾向を示す. また，球間ピッチの影響として，

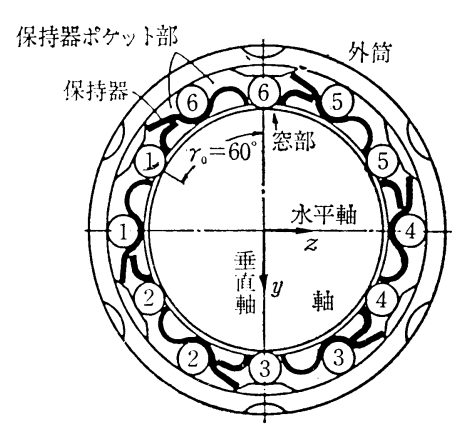

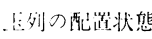

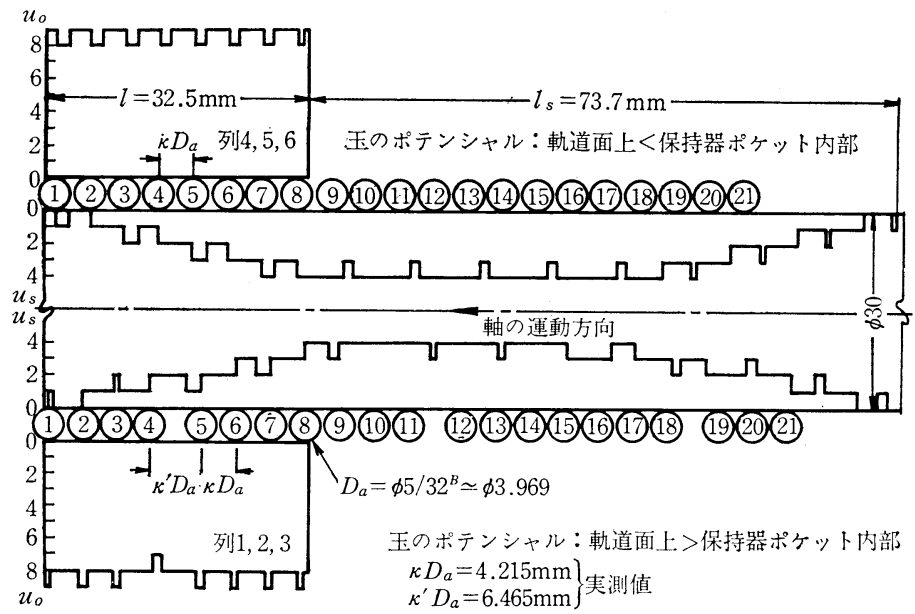

図 7 各軌道面における 1 ストローク当たりの応力絽返し数

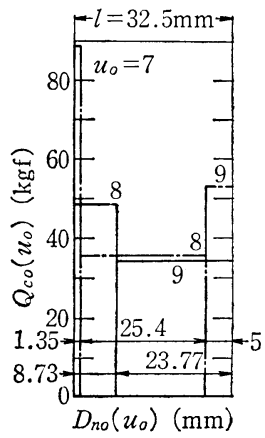

(a) 外筒の場合

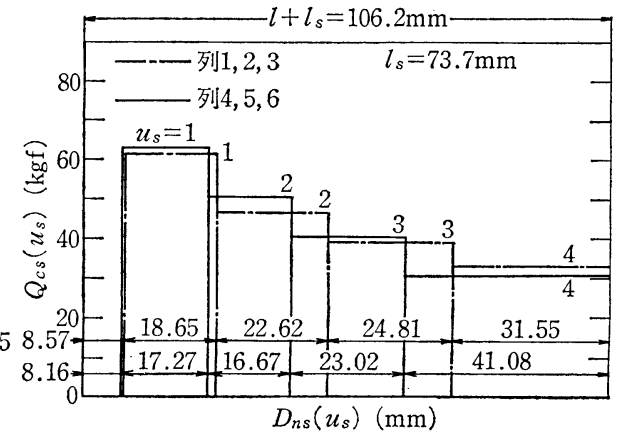

（b）軸の場合

図 8 応力繰返し数と応力を受ける長さならびに各部の転動体荷重の関係

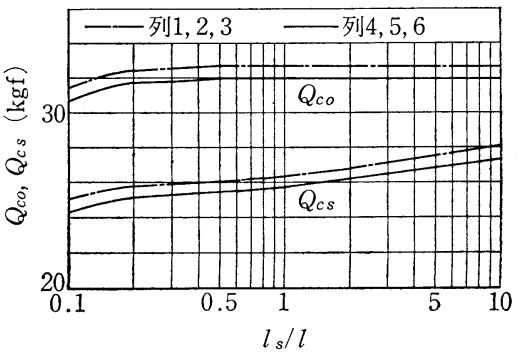

図 9 軸ストロークと基本動定格荷重に対す る 1 列全体としての転動体荷重の関係 （直動玉軸受の場合） 


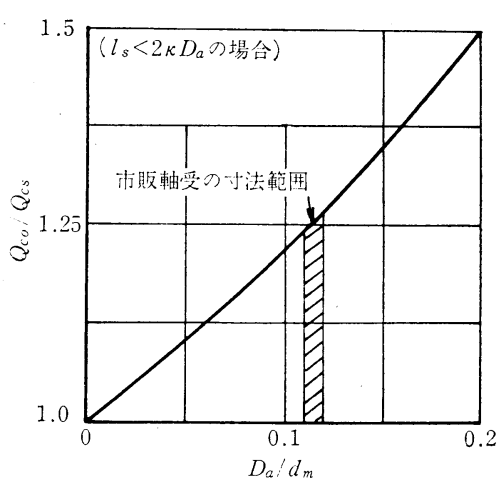

図 $10 D_{a} / d_{m}$ と $Q_{c o} / Q_{c s}$ との関係

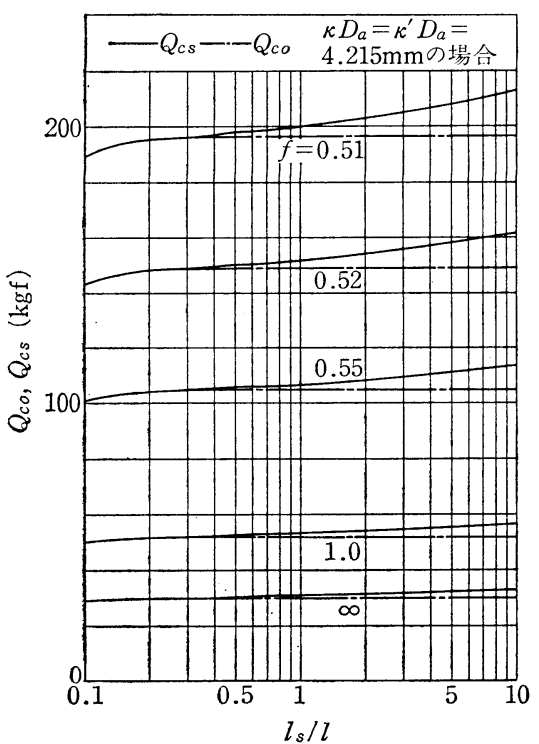

$f=0.51 \sim 0.55:$ ボールスプライン, $f=\infty$ : 転がり案内

図 11 ボールスプラインや転がり案内の場合における $l_{s} / l$ と $Q_{c i}$ との関係

$\boldsymbol{\kappa}^{\prime} D_{a}$ の現れる列 $1,2,3$ は列 $4,5,6$ より $Q_{c i}$ が高いこと， また軸よりも外筒側の転動体荷重がはるかに高いことが わかる。

いま，微小ストローク時，すなわち $l_{s}<2 \kappa D_{a}$ の場合 に打ける $Q_{c o} / Q_{c s}$ を $D_{a} / d_{m}$ の関係で表すと図 10 を得 る.ここで, 斜線部は市販軸受の寸法範团を示す.これ より，外筒は軸に比べて $25 \%$ も転動体荷重が大きく，し たがって直動玉軸受の転動疲れ剝離現象は理論上からい えば軸軌道面から生起する確率が高いといえる。

また，ボールスプラインや転がり案内の場合における $l_{s} / l$ と $Q_{c i}$ との関係は図 11 に示す. この場合は $l_{s} / l$ が 1 を越えると軸転動体荷重が外筒転動体荷重をかなり上回
り，この傾向は玉と軌道みぞの形状一致性が高いほど顕 著になる. 一方, 形状一致性が低下すると転動体荷重は 極端に低減し， $f \rightarrow \infty$ すなわち転がり案内の場合になる とほとんど直動玉軸受の場合と差異がなくなってくる.

\section{4.むす び}

直動玉軸受の寿命理論に関する第 1 報として，軸受外 筒ならびに軸軌道面に怙ける応力繰返し数の計算法を考 案し, ボールスプラインや転がり案内も包含した転動体 荷重の一般式を導き，軸ストロークに対する計算値に検 討を加えた。

結果を要約すると次のようである。

（1）軸受外筒ならびに軸軌道面を微細に分割してその 応力繰返し数を計算する方法を用いると，外筒の場 合は玉通過数を，軸の場合は玉追越し数を算出する ことによって各部の応力繰返し数を正確に把握でき ることがわかった.

（2） ある軸ストロークに护ける軌道面各部の転動体荷 重は応力繰返し数と応力を受ける長さが小さいほど 大きくなる．しかし，1列全体としての転動体荷重 は微小ストローク時ではかなり小さく, 軸ストロー クと外筒軌道面長さとの比 $l_{s} / l$ が 1 以上になると外 筒側の転動体荷重 $Q_{c o}$ は一定值をとるようになり, 軸側の転動体荷重 $Q_{c s}$ は増大率がかなり高くなるこ とがわかった。

(3) 市販の直動玉軸受では，一般に $Q_{c o} / Q_{c s}=1.25$ と なっていて, 転動疲れ虽離は軸側から生起する確率 が高いと考觉らる、一方，ボールスプラインでは $l_{s} / l \leqq 1$ の場合 $Q_{c o} / Q_{c s}=1$ であるが， $l_{s} / l=10$ にな ると $Q_{c o} / Q_{c s} \simeq 0.92$ となり，外筒から疲れ剥離が生 起する確率が高くなると考えられる。また，ボール スプラインの玉と軌道みぞとの形状一致性が低下す ると転動体荷重は極端に低減し，さらに転がり案内 になると直動玉軸受の転動体荷重にほぼ等しくなる ことがわかった。

\section{参 考 文 献}

1) G. Lundberg \& A. Palmgren: Dynamic Capacity of Rolling Bearings, IVA Handlinger, 196, (1947).

2）高田浩年：リニャーボールベアリングの負荷容量，NSK Bearing J., 625 (1970) 1.

3）例えば，清水茂夫, 井沢 実：直動球軸受の負荷分布に関 する研究 (第 5 報)，精密機械， 45，2 (1979) 154.

4）井沢 実, 清水茂夫：直動球軸受の負荷分布に関する研 究, 昭和 53 年度精機学会春季大会学術講演会前刷 (1978) 113. 